\title{
Differences between genotypes of tomato (Lycopersicon esculentum Mill.) in net photosynthesis, light absorption by leaves, chlorophyll content and specific leaf fresh weight under low-energy conditions
}

M. Nieuwhof and S. J. van de Dijk (Institute for Horticultural Plant Breeding, P.O. Box 16, NL 6700 AA Wageningen, Netherlands)

Received 2 June 1988; accepted 19 October 1988

\begin{abstract}
Differences in net photosynthesis between genotypes of tomato can be mainly attributed to differences in the capacity of the leaves to absorb light. Variation in chlorophyll content and leaf thickness largely explained the differences in light absorption. Genotypes with large thin leaves, in combination with a high chlorophyll content, may be best adapted to low-energy conditions.
\end{abstract}

Key words: Lycopersicon esculentum, tomato, genotypical variation, chlorophyll, leaf thickness, light absorption, photosynthesis, temperature

Introduction. Genotypical differences in net photosynthesis of tomato grown under low-energy conditions have been established (van de Dijk \& Maris, 1985). In the present study the causes of genotypical differences in photosynthesis when grown under low light intensity at three night temperatures (NT) were investigated. Of 16 genotypes grown at three NTs, photosynthesis, specific leaf fresh weight (SLFW), chlorophyll content and light absorption by the leaves were determined.

Materials and methods. The genotypes used are described by Smeets \& Garretsen (1986) and Nieuwhof et al. (1987). Seeds were sown at $25^{\circ} \mathrm{C}$ in 4 replicates. At Day 13, temperature was lowered to $19 / 14^{\circ} \mathrm{C}$ DT/NT. At Day 30 , NTs were set at 14,10 and $6{ }^{\circ} \mathrm{C}$. RH was $70 \%$, day length $8 \mathrm{~h}$ and light intensity $24 \mathrm{Wm}^{-2}$ visible light.

Photosynthesis, chlorophyll content and SLFW were determined at Days 38-44, 49-56, 60-66 and 70-77. Net photosynthesis of the youngest expanded leaf was measured as described earlier, at $40 \mathrm{Wm}^{-2}$ visible light (HPL-N lamps) and $19{ }^{\circ} \mathrm{C}$ (Van de Dijk \& Maris 1985). Leaf area was measured with a LI-COR Area Meter. Chlorophyll content of these leaves was determined as described by Bruinsma (1963). At the last three harvests of top leaflets, light transmission and reflection were measured with a Beckman spectrophotometer connected with an Ulbrichttype integrating sphere. Wavelength range was limited to between 475 and $675 \mathrm{~nm}$. Losses of radiation energy by transmission and reflection were expressed as percentages of the total radiation energy. 
Per plot, a time curve of each character was obtained that is characterized by the parameters $m$ (level), $l$ (slope) and $q$ (curvature). Differences in the curves were analysed by multiple analysis of variance (Keuls \& Garretsen, 1982).

Results. Significant genotypical differences were assessed for net photosynthesis per square decimetre leaf area $\left(P_{\mathrm{A}}\right)$, SLFW, chlorophyll content expressed per gram fresh weight $\left(C(a+b)_{\mathrm{FW}}\right)$ and per square decimetre leaf area $\left(C(\mathrm{a}+\mathrm{b})_{\mathrm{A}}\right)$, and for light transmission and reflection (Table 1).

For $P_{\mathrm{A}}$, a genotype $\times$ NT interaction was found. $P_{\mathrm{A}}$ was hardly affected by NT and increased with time for almost all genotypes and NT's.

Genotype $\times$ NT interactions for SLFW were also found. SLFW was higher at lower NT. At NT $6{ }^{\circ} \mathrm{C}$, SLFW increased with time. At higher NT's this was not always the case.

For chlorophyll content, some genotype $\times$ NT interactions occurred. No effect of NT on $C(\mathrm{a}+\mathrm{b})_{\mathrm{FW}}$ was present. The higher content of $C(\mathrm{a}+\mathrm{b})_{\mathrm{A}}$ at lower NTs may be due to a higher SLFW. Chlorophyll content increased with time.

For light transmission, some genotype $\times$ temperature interactions occurred. At NT $6{ }^{\circ} \mathrm{C}$, light transmission was lower than at higher NTs. For light reflection, no effect of NT was found. A decrease with time was observed for transmission and reflection. This decrease was lowest at $6{ }^{\circ} \mathrm{C}$.

Light absorption $\left(100 \%\right.$-transmission - reflection) was highest at NT $6{ }^{\circ} \mathrm{C}$. This may be attributed to a high SLFW (thick leaves) at NT $6{ }^{\circ} \mathrm{C}$, which resulted in a higher $C(\mathrm{a}+\mathrm{b})_{\mathrm{A}}$. Light absorption generally increased with time as a result of a simultaneous decrease of light transmission and light reflection. These effects may be due to an average increase of SLFW at NT $6{ }^{\circ} \mathrm{C}$ and $10^{\circ} \mathrm{C}$, as well as to an average increase of $C(\mathrm{a}+\mathrm{b})_{\mathrm{FW}}$ with time. At NT $14^{\circ}$, the effect of $C(\mathrm{a}+\mathrm{b})_{\mathrm{FW}}$ was largest and that of SLFW smallest. At $6{ }^{\circ} \mathrm{C}$, the reverse was the case.

Significant correlation coefficients occurred between light transmission and light reflection $(0.76)$, light transmission and light absorption $(-0.98)$ and light reflection

Table 1. Genotypical variation for net photosynthesis $\left(P_{\mathrm{A}} ; \mathrm{mg} \mathrm{CO}_{2} \mathrm{dm}^{-2} \mathrm{~h}^{-1}\right)$, specific leaf fresh weight (SLFW; $\left.\mathrm{g} \mathrm{dm}^{-2}\right)$, content of chlorophyll $(\mathrm{a}+\mathrm{b})_{\mathrm{FW}}\left(\mathrm{mg} \mathrm{g}\right.$ fresh leaf $\left.\mathrm{wt}^{-1}\right)$ and content of chlorophyll $(\mathrm{a}+$ b) ${ }_{\mathrm{A}}\left(\mathrm{mg} \mathrm{dm} \mathrm{dm}^{-2}\right.$ leaf area), and transmission and reflection of light (expressed as percentages of the incident radiant energy at wavelengths between 475 and $675 \mathrm{~nm}$ ) at three night temperatures. L: genotype with lowest value, $\mathrm{H}$ : genotype with highest value.

\begin{tabular}{|c|c|c|c|c|c|c|}
\hline \multirow[t]{2}{*}{ Characteristic } & \multicolumn{2}{|l|}{$14^{\circ} \mathrm{C}$} & \multicolumn{2}{|l|}{$10^{\circ} \mathrm{C}$} & \multicolumn{2}{|l|}{$6^{\circ} \mathrm{C}$} \\
\hline & $\mathrm{L}$ & $\mathrm{H}$ & $\mathrm{L}$ & $\mathrm{H}$ & $\mathrm{L}$ & $\mathrm{H}$ \\
\hline$P_{\mathrm{A}}$ & 10.5 & 12.9 & 10.2 & 12.9 & 10.4 & 12.3 \\
\hline SLFW & 1.16 & 1.61 & 1.30 & 1.94 & 1.48 & 2.32 \\
\hline$C(\mathrm{a}+\mathrm{b})_{\mathrm{FW}}$ & 2.2 & 3.3 & 2.4 & 3.3 & 2.4 & 3.2 \\
\hline$C(\mathrm{a}+\mathrm{b})_{\mathrm{A}}$ & 2.9 & 4.6 & 3.2 & 5.1 & 4.1 & 6.5 \\
\hline Transmission & 7.5 & 12.2 & 6.9 & 11.7 & 6.2 & 9.4 \\
\hline Reflection & 8.3 & 10.4 & 8.4 & 10.3 & 8.0 & 9.5 \\
\hline
\end{tabular}


Table 2. Correlation coefficients between $P_{\mathrm{A}}$, SLFW, $C(\mathrm{a}+\mathrm{b})_{\mathrm{FW}}, C(\mathrm{a}+\mathrm{b})_{\mathrm{A}}$ and light absorption. Averages of three night temperatures.

\begin{tabular}{lllll}
\hline & SLFW & $C(\mathrm{a}+\mathrm{b})_{\mathrm{FW}}$ & $C(\mathrm{a}+\mathrm{b})_{\mathrm{A}}$ & Light absorption \\
$P_{\mathrm{A}}$ & -0.39 & 0.46 & 0.05 & $0.43^{*, 1}$ \\
SLFW & & 0.07 & $0.65^{* *}$ & 0.19 \\
$C(\mathrm{a}+\mathrm{b})_{\mathrm{FW}}$ & & $0.52^{*, 1}$ & $0.67^{* * 1}$ \\
$C(\mathrm{a}+\mathrm{b})_{\mathrm{A}}$ & & $0.69^{* *}$ \\
\hline${ }^{*} 0.01<P<0.05 ;{ }^{* *} 0.001<P<0.01$. & \\
${ }^{1}$ Not significant at NT $6^{\circ} \mathrm{C}$.
\end{tabular}

and light absorption (-0.87). Table 2 shows that positive correlations occurred between $P_{\mathrm{A}}$ and light absorption, SLFW and $C(\mathrm{a}+\mathrm{b})_{\mathrm{A}}$, and chlorophyll content and light absorption. Between $P_{\mathrm{A}}$ and SLFW a negative, but not significant, correlation was found.

Discussion. The chlorophyll contents have about the same variation as those reported for tomato under low-energy conditions by Preil (1976). A content of $C(\mathrm{a}+$ b) $)_{\mathrm{A}}$ of $5-6 \mathrm{mg} \mathrm{dm}^{-2}$ is considered optimal (Gabrielson, 1960). Only at NT $6{ }^{\circ} \mathrm{C} \mathrm{did}$ most genotypes approximate this value, largely due to a high SLFW.

Differences in light absorption between genotypes at the three NTs can be largely explained by differences in chlorophyll content. Light absorption differences may also be attributed to optical properties of leaves that are related to cell size, patterns of veins, hairs, starch grains and pigments.

Light energy absorbed by chlorophyll is available for $\mathrm{CO}_{2}$ fixation in photosynthesis so a significant correlation between $P_{\mathrm{A}}$ and light absorption can be expected. To obtain a better measure of total $\mathrm{CO}_{2}$ fixation, $P_{\mathrm{A}}$ should be corrected for the $\mathrm{CO}_{2}$ losses by dark respiration. After adding dark respiration $\left(R_{\mathrm{A}}\right.$; data from van de Dijk, 1987) to $P_{\mathrm{A}}$ the correlations between $P_{\mathrm{A}}+R_{\mathrm{A}}$ and light absorption for 14 genotypes were $0.73,0.77$, and 0.66 for the $3 \mathrm{NTs}$ at 14,10 and $6{ }^{\circ} \mathrm{C}$, respectively. Thus it may be concluded that differences in total $\mathrm{CO}_{2}$ fixation can be attributed for a large part to differences in light absorption. Differences in $P_{\mathrm{A}}$ are partly the result of a combined effect of differences in light absorption and dark respiration.

SLFW seems an important determinant of $C(\mathrm{a}+\mathrm{b})_{\mathrm{A}}$. However, a high SLFW is less efficient than a low SLFW with respect to dry matter production per plant as SLFW correlates negatively with leaf area (Smeets \& Garretsen, 1986). Therefore, genotypes with a low SLFW and a high $C(\mathrm{a}+\mathrm{b})_{\mathrm{A}}$ may be best adapted to low-energy conditions.

\section{References}

Bruinsma, J., 1963. The quantitative analysis of chlorophylls a and b in plant extracts. Photochemistry \& Photobiology 2: 241-249.

Dijk, S. J. van de, 1987. Inheritance of net photosynthesis, dark respiration, stomatal resistance and related characters in tomato (Lycopersicon esculentum Mill.) under low energy conditions. Euphytica 36: 193-203. 


\section{DIFFERENCES BETWEEN GENOTYPES OF TOMATO}

Dijk, S. J. van de and J. A. Maris, 1985. Differences between tomato genotypes in net photosynthesis and dark respiration under low light intensity and low night temperatures. Euphytica 34: 709-716.

Gabrielson, E. K., 1960. Chlorophyllkonzentration und Photosynthese. Hdb. Pflanzenphysiologie V/2, p. 156-167.

Keuls, M. and F. Garretsen, 1982. Statistical analysis of growth curves in plant breeding. Euphytica 31: 51-64.

Nieuwhof, M., G. Pet and F. Garretsen, 1987. Inheritance of characters determining growth and development of tomato (Lycopersicon esculentum Mill.) under low energy conditions. Euphytica 36: 205213.

Preil, W., 1976. Zur Beziehung zwischen den Chlorophyll-gehalt der Blätter und dem Fruchtertrag bei Tomaten während der Gewächshaus-Winterkultur. Gartenbauwissenschaft 41: 248-252.

Smeets, L. \& F. Garretsen, 1986. Growth analyses of tomato genotypes grown under low night temperatures and low light intensity. Euphytica 35: 701-715.

This synopsis is based on a report by S. J. van de Dijk and M. Nieuwhof, entitled 'Differences between genotypes of tomato (Lycopersicon esculentum Mill.) in net photosynthesis, light absorption by leaves, chlorophyll content and specific leaf fresh weight under low energy conditions'. Report No 248, Institute for Horticultural Plant Breeding, P.O. Box 16, 6700 AA Wageningen, 1988.17 pp., 5 tables, 16 refs. Available as paper copy (order $R 086 P, f 15$ including postage) at: NARD, c/o Pudoc, P.O. Box 4, 6700 AA Wageningen (telex 45015 blhwg nl). 